\title{
MAJORITY SHAREHOLDER ; LARGE SHAREHOLDER, FAMILY OWNERSHIP, INSTITUTION OWNERSHIP AND ITS IMPACT ON FIRM PERFORMANCE
}

\author{
Artalia Indah Roossiana \\ Swiss German University, Tangerang, Indonesia
}

\author{
Yosman Bustaman \\ Swiss German University, Tangerang, Indonesia
}

We investigate the impact of majority shareholder that categorizes as large shareholder, family ownership and institution ownership on the firm performance measured by accounting performance ROA and market performance namely Tobin Q. This research concentrate on Consumer Goods Sector Companies listed on the Indonesia Stock Exchange (IDX) covering from year 2011 to year 2014. We use unbalanced panel data analysis. After controlling with firm specific variables; such as size of company, age, leverage, growth and macro economic variables, we find that large shareholder without knowing who the owners are do not affect the firm performance. However, when the family and institution become dominance in controlling the company, market reacts negatively. It might occur because market perceives negative effect of disgorging cash by family and institutional that cause lower distribution profit for other minority shareholder in the market. Our finding provides the signal for company which majority of shareholder is family and institutions, they have to be alert that market judge negatively so that they probably need to provide more transparence report on flowing the cash flows of company. Additionally for the new investors who expect to have capital gain on the investment must take fully concern on this condition, because their value of investment could decrease and get loss if they invest in this type of companies 


\section{INTRODUCTION}

$\mathrm{A}$ company that has great value tends to generate greater wealth for the shareholders. Raising the value of the company such as considering the time value of money is more important than maximizing profit of the company (Haruman, 2008). According to Abukosim, Mukhtaruddin, Ferina and Nurcahaya (2014), investors decide to invest their money, if the company has a high value and. Subsequently the firm's value is affected by ownership structure. Ownership structure has significant role in determining the firm's value (Abukosim et al 2014).

Ownership concentration concern on how and who has the obligation to manage the corporate ownership. Generally the majority of shareholders have the authority to the company's business activities. Isik and Soykan (2013) stated that dominance share who involve in managing the firm may leads to agency problems. Agency problem arises because the large shareholders have more incentive to observe and control managers (AlSaidi \& Al-Shammari, 2014). Therefore, large shareholders have a chance to manipulate the firm and take over the small shareholders voting rights..

Some scholars provide evidence that large shareholders could help in improving the firm performance. Isik and Soykan (2013) stated that improved firm performance means able to hire more employees, able to pay more taxes, and able to export to other nations. Additionally, the lack of large shareholder may endanger the firm existence aside from the downturn in the firm performance.

Since 1998, Indonesia has been going through long term crisis because the corporate governance in Indonesia has an inadequate post crisis solution. The segregation of company control of ownership is the concern of corporate governance. The shareholder structure is related to the rising value of the company is a crucial problem with regards to the corporate governance (Abukosim et al 2014). Most of corporate in Indonesia are organized by family corporation (Claessens, Djankov, \& Lang, 2000),. Family ownership could decrease the agency cost, reduce the conflicts and improve firm value. Shyu (2011) stated that family firms may eliminate agency problems from the results of conflict amongst shareholders and managers; have the ability to enhance firm performance by organizing the managers. Additionally, Arosa, Iturralde and Maseda (2009) found that ownership and firm performance rely on which generation of the family managers. First generations of family firms indicate a positive association between concentrated ownership and firm performance with low control rights.

Large shareholders may exploit the firm and take control of the small shareholders. The separation of control in public firms and the ownership of shares may leads to agency problems resulted from the decision inconsistency between small shareholders and the managers (Isik \& Soykan, 2013). Therefore, the purpose of this research is to examine the correlation between large shareholder and the firm performance that will be measured by Tobin's Q and Return on Asset (ROA). In this research, share owned by the largest shareholder group are divided into two groups, which depends on the levels of ownership; they own more than 10 percent to 50 percent and large shareholder that own more than 50 percent. We also will explore the impact of family and institutional ownership on firm performance. 
This research will concentrate on Consumer Goods Sector Companies listed on the Indonesia Stock Exchange (IDX). This sector was selected because consumer goods has the biggest gross domestic product from 2011-2014 (SDSS, 2014). More over, studies related to this topic that analyze Indonesian firms are very view, so that we expect that our study can enhance the literature on ownership structure and firms' performance.

Our findings show that large-shareholder positively impact firm performance that measured by ROA, and negatively impact Tobin Q. However, these findings are not significant. Institutional ownership could booster firm accounting performance, however when proportion of institutional and family ownership becomes larger market reacts negatively. It might occur because market perceives negative effect of disgorge cash by family and institutional that cause lower distribution profit for other minority shareholder in the market.

This research article is structured as follows; section 2 presents the literature review on the subject and the follows by the data and methodology in section 3. Section 4 describes the descriptive statistics, research finding and analysis. Then in section 5 we conclude our study and the implication of the research.

\section{LITERATURE REVIEW II.I Capital Structure}

Capital structure is the association between debt and equity (Pandey, 2009). Meanwhile, capital structure refers to a section of long-term debt and equity that being utilized to reach investment needs (Siddaiah, 2010). The definition of capital structure based on Baker \&
Martin (2011) is defined as the debt, equity, and securities that used to allocate the assets, operations, and future growth. To conclude, capital structure consists of equity and debt financing of a firm that measured to reduce the cost of capital and increase the firm's value.

According to Mireku, Mensah, and Ogoe (2014), the ideal mix of equity and debt that exist is the main purpose of engaging researcher attention and the capital structure will continually increase time after time. Capital structure operated among the rise of debt level and without triggering fundamental rise in agency costs (Chinaemerem \& Anthony, 2012). These conflicts may happen in conditions where managers have incentives to take excessive risks as part of risk shifting investment strategies. According to Hasan, Ahsan, Rahaman and Alam (2014), the decision that is poorly planned decisions will jeopardize the firm, for instance if the cost of capital increase, it will decrease the firm performance. Meanwhile, the applicable capital structure might do the contrary. The important choices of the firm are the capital structure decisions because it will impact the cost of capital and firm value (Twairesh, 2014).

Based on previous studies of Nirajini \& Priya (2013), it shows that there is a significant positive correlation between capital structure and financial performance. To have income constantly and able to be going concern, firms should make good capital structure decision. Meanwhile according to the other studies of Jaisawal, Srivastava and Sushma (2013), there is inadequate positive relationship between capital structure and performance of gross profit ratio (GPR) and ROE. Financial performance consist of net profit ratio (NPR), return on capital employed (ROCE) and return on assets 
(ROA) which are all negatively correlated with capital structure.

\section{II.II. Ownership Structure - Agency Problems}

Agency problem emerges when agents and principals (management and shareholders) have a conflicts of interest possibility (Wright, Siegel, Keasey, \& Filatotchev, 2013). Agency problem is a clash between agents and principal happens when agents decide to improve shareholders prosperity but the decision may not going as planned (Petty, et al., 2011). Agency problems refer to a conflict between the purpose of agents and principals (Graham \& Smart, 2011). In conclusion, agency problem is a conflict of interest between agents and principals.

Agency problems arise when a firm's owner and management, or controlling and non-controlling shareholder do not perform based on the interest of shareholders (Charitou \& Louca, 2014). Agency problems can be reduced by increasing the level of managerial ownership and concentrated ownership, which assume to be internal control procedure such as positive monitoring (Laiho, 2011).

\section{II.III. Ownership Structure and Firm Performance}

Ownership structure is the amounts of ownership claims held by management and investors (Chen, 2004). The relationship between ownership structure and firm performance in McConnell and Servaes (1995) that was quoted by Margaritis \& Psillaki (2008), said that ownership structure rate of importance will change depends on high and low growth rate of the firms. Their conclusion is that ownership structure tends to be more important in low-growth compare to high-growth firms.

Ownership structure is the firm's stock ratio which can be examined from the ownership concentration and composition (Foroughi \& Fooladi, 2012). Based on previous study by (Demsetz \& Villalonga, 2001), ownership structure have no significant relationship with firm performance because every ownership structure in each company deal with different circumstances, such as the scale of economics and the environment stability in which they operate.

Concentrated ownership means that the majority (large) firm ownership is held by controlling shareholder (Wright, Siegel, Keasey, \& Filatotchev, 2013). In the other hand, based on Lessambo (2013), concentrated ownership refers to the percentage of firm's ownership that held by controlling shareholder. Concentrated ownership is defined as the large percentage of shares in the company that hold by the shareholders (Hitt, Ireland, \& Hoskisson, 2012). In brief, concentrated ownership refers to the percentage of ownership of a firm owned by controlling shareholder.

It is common in developing countris that firms' ownership is concentrated on certain group of owners (Al-Saidi \& Al-Shammari,2014). Ownership concentration examines the percentage of share that owned by total shareholder of the firm while major shareholders are measured by ownership identity (Ongore, 2011).

Foroughi and Fooladi (2012) saw that ownership concentration has negative correlation with firm performance. It means the greater ownership concentration offers shareholder a greater opportunity. Meanwhile, Abbas et al (2013) found that 
concentrated ownership have a positive impact on firm value. These authors use proportion of ownership by largest owners as concentration ownership meanwhile performance of company measured by Tobin's Q. Arosa, Iturralde, \& Maseda (2009) shows that the certain degree of concentration could jeopardies minority shareholder because large shareholders tend to spew firm cash flows on the cost of minority shareholder.

According to Abdullah, Shah \& Khan (2012), large shareholders have appropriate behavior on observing and decreasing transaction costs they spent and they also perform well in contracts with stakeholders of the firm. Nevertheless, large shareholders have costs as well simultaneously. According to King, Tian \& Zhang (2009), large shareholders are common over the world and have significant effects on firm value.

Al-Saidi \& Al-Shammari (2014) suggest that the ownership concentration towards firm performance has negative impact since the large shareholders use the firm's resources for their own benefit from the expense of minority shareholders. Shleifer \& Vishny (1986) stated that large shareholders tend to have strong incentive to observe managers because of the significant of economic stakes.

\section{METHODOLOGY III.I. Data}

This research uses 35 consumer goods companies listed in Indonesian Capital Market, consist of 17 of foods and beverages companies; 3 household companies; 3 tobacco companies; 9 pharmaceutical companies, and 3 cosmetics companies. There are five years period will cover in this paper starting from year 2010 to year 2014. This secondary data are taken from each company's' financial reports downloading from firms' web site. We also test the impact of macro economic variables in our model, they are growth of gdp and inflation rate. These macro-economics variables are taken from Indonesian Statistics Biro.

\section{III.II. Empirical Model}

This research apply unbalanced panel data model analysis to examine the impact of ownership on firm's performance.

$$
P E R_{i t}=\alpha+\sum_{i i}^{n} \beta_{i} D O W N_{i t}+\sum_{i i}^{k} \theta_{i} C S_{i t}+\sum_{i i_{i}}^{j} \gamma_{i} M E_{i t}+\varepsilon_{i t} \ldots \ldots(1)
$$

\section{III.II.I. Dependent variable}

PER is company performance that consists of accounting measurement performance Return on Asset (ROA) and market indicator performance Tobin's Q. ROA is a measurement of how profitability of a firm is associated to its total assets. It shows how effective the management utilized the assets to generate profits (Ahmed et al, 2012). The higher this ratio the higher the level of company performance will be (D'Amato, 2010). The equation to estimate the ROA is follows

$$
R O A=\frac{\text { Net Income }}{\text { Average Total Asset }} \times 100 \%
$$

Other alternative performance measurement is Tobin's Q. It was presented by James Tobin in 1969 and known as total market value of the firm divided by the book value of total assets of the firm (Hasan et al, 2014). Tobin's Q comparing a company's market value and the current book value to increase the prosperity of investors (Network for Business Sustainability, 2015). 
Tobin's $Q=\frac{\text { Market Value of Equity }}{\text { BV of Total Assets }} \times 100 \% \ldots \ldots$ (3)

Karaca \& Ekşi (2012) and Alipour (2013) used this performance ratio to determine whether largest shareholder affect the company's performance.

\section{III.II.II. Ownership Dummy Variables}

DOWN is ownership dummy variable, first dummy variable (D1) is used to capture whether there is an existence of large shareholder who will affect the firm performance. We divide the large shareholder who own 10\%-50\% ownership and second one is the owner who own more than $50 \%$ proportion. To identify the ownership, it takes the value of 1 if ownership is larger than $50 \%$ and 0 otherwise. Isik \& Soykan (2013) found that the higher the levels of ownership by large shareholders the worst firm performance in Turkey.

Second dummy variable (D2) uses to identify whether the company own by the family. Firm is considered own by family firms if the firm held by one of the family members who founded the firm; or take over from someone else as a result of an acquisition or merger (Khan \& Khan, 2011). Growth of family ownership helps to reduce agency problems because family firms tend to be less conflict (Shyu, 2011). Sacristán-Navarro et al (2011) indicates that family ownership have insignificant impacts on profitability and appears to matter about the presence of family in firm's management and/or on the board of directors. Additionally Pindado et al (2008) show that family ownership impacts positively on firm value. Family firm is variable that equals one (1) when the founding family is present in the firm management and zero (0) if otherwise.

Institutional ownership is defined as the fraction of a firm's shares held by institutional investors (Chung \& Zhang, 2009). Institutional investors have strong reasons to monitor managers in effective way because the large ownership in the firm and their large resources allowing them to identify the efficient firms. Monitoring will improve the efficiency of management and the quality of making decision including mergers and acquisitions (André \& Ben-Amar, 2008).

Institutional investors monitor managers in effective way because large shareholders allow to admit the efficiency of the firm (André \& Ben-Amar, 2008). According to Charfeddine and Elmarzougui (2010), Tobin's Q has negative relationship with institutional firms. Institutional firm is variable that equals one (1) when the other company is present in the firm, and zero $(0)$ otherwise.

\section{III.II.III. Control Variables}

Firm size has been used in many researches as control variable. Large firms size known as an ideal firms and tend to have great performance in previous years. According to Shyu (2011), the relationship between firm size and firm performance have a positive association because larger firms size are tend to be more effective and efficient in the usage of assets and advantages from economies of scale.

Theoretically, firm size measured by using total assets (Hasan et al 2014). Firm size is important to determine the firm performance. Large firm estimated to have various in product contribution to reduce the risk of bankruptcy (Abdullah , Shah, \& Khan, 2012). Jebri (2013) used firm size using natural logarithm of the book value of total assets. It is crucial to manage firm size by the book value of its 
assets, since most of bigger firms have chance to have less growth compare with smaller firms (Laiho, 2011, Abbas et al 2013).

Another firm specific variable is leverage. It is measured by the ratio of debt to equity of firm. Leverage requires to prevent uncertain outcome because the particular variables of firm may impact the result (Abbas, Naqvi, \& Mirza, 2013). Debt has lower form of financing and contains threats and investor should be more responsive of the threats (D'Amato, 2010). Debt has an important effect on agency costs. Firms with greater levels of debt tend to be tight scrutinized by the debt holders (McKnight \& Weir, 2009). There are a possibility that debt has positive effect on profitability, debt is used to acquiring assets and expectedly to improve procedures the net profits (D'Amato, 2010). Leverage can be measured by comparing the total debt to shareholder's equity or called debt to equity ratio.

Firm's age tend to determine the capability of its firms. Older firms are expected to have greater ability to sustain customer loyalty, discover new sectors and markets compare with younger firms. Firm's performance is estimated to be positively associated to age of the firm (Seetanah et al 2014). Age of firm is measured as the natural logarithm of the number of years since the establishment of the firm as used by Arosa, et al (2009).

Sales growth improves earnings when sales are lower than the optimal level. If sales are above the optimal level, the sales growth will reduce firm's earnings (David, O’brien, Yoshikawa, \& Delios, 2010). Sales growth is more precise in the firm performance than other accounting measures (Barbera \& Hasso, 2013). Sales growth is measured as:

$$
\frac{\text { Sales }(t)-\text { Sales }(t-1)}{\text { Sales }(t-1)} \times 100 \%
$$

Sales growth measured as another indicator of future growth opportunities. Low sales growth will have less opportunities to replace low risk for high risk and high return investments; therefore they should conduct lower agency costs of debt and should capable to bring more debt in their capital structure (Margaritis \& Psillaki, 2008).

\section{III.II.IV. Macro-Economic Variables}

Gross Domestic Product (GDP) described as market value of goods and services produces by one country over specific period of time. It is one of the primary indicator to gauge the health of country's economy. The growth rate of gdp measures how fast the economic growth in one country. The higher the growth of economic the higher expected firms' performance. Another macro economic factor is inflation rate. Inflation means the common value level in period of time that continue to increase (Dwivedi, 2010). It is also noted that inflation rate and economic growth are likely to affect the quality of firm assets and performance (Beck et al., 2006).

\begin{tabular}{|c|c|c|}
\hline Variables & \multirow[b]{2}{*}{ Description } & \multirow[b]{2}{*}{ Symbol } \\
\hline $\begin{array}{l}\text { Performance } \\
\text { Measures: }\end{array}$ & & \\
\hline ROA & The ratio of net income to total assets & ROA \\
\hline Tobin's Q & $\begin{array}{l}\text { Market value of equity divided by book } \\
\text { value of total assets }\end{array}$ & TOBQ \\
\hline \multicolumn{3}{|l|}{$\begin{array}{l}\text { Independent } \\
\text { Variables }\end{array}$} \\
\hline \multicolumn{3}{|l|}{$\begin{array}{l}\text { Ownership Structure } \\
\text { Dummy: }\end{array}$} \\
\hline $\begin{array}{l}\text { The large shareholder } \\
\text { holds }(50 \%-100 \%)\end{array}$ & $\begin{array}{l}\text { Dummy variable, the value of } 1 \text { if the large } \\
\text { shareholder has more than } 0.50 \% \text { of the } \\
\text { firms' shares, otherwise } 0 .\end{array}$ & D1 \\
\hline Family & $\begin{array}{l}\text { Family ownership is variable that equals } \\
\text { one (1) when the founding family is present } \\
\text { in the firm, and zero }(0)\end{array}$ & D2 \\
\hline Institutional & $\begin{array}{l}\text { Institutional ownership is variable that } \\
\text { equals one (1) when the founding family is } \\
\text { present in the firm, and zero ( } 0 \text { ) }\end{array}$ & D3 \\
\hline \multicolumn{3}{|l|}{ Control Variables } \\
\hline Size & Natural logarithm of total assets & $\mathrm{SZ}$ \\
\hline Age & $\begin{array}{l}\text { The number of years since the } \\
\text { establishment of the firm }\end{array}$ & AGE \\
\hline Sales Growth & Average growth in net sales & GROWTH \\
\hline Leverage & Ratio of long term debt to equity & LEV \\
\hline \multicolumn{3}{|l|}{$\begin{array}{l}\text { Macroeconomics } \\
\text { Factors }\end{array}$} \\
\hline GDP grwoth & The growth of economy & GDPG \\
\hline Inflation & Inflation rate & INF \\
\hline
\end{tabular}




\section{RESULTS AND DISCUS- SION}

\section{IV.I. Descriptive Statistics}

Table 2 the descriptive statistics
\begin{tabular}{|l|l|r|r|r|}
\hline Variables & $\begin{array}{l}\text { No of } \\
\text { Observation }\end{array}$ & \multicolumn{1}{l}{ Mean } & \multicolumn{1}{l}{ Max } & \multicolumn{1}{l|}{ Min } \\
\hline ROA & 159 & 0.1169 & 0.6547 & -.2339 \\
\hline TOBQ & 145 & 14.0496 & 227.5291 & 0.0997 \\
\hline $\begin{array}{l}\text { Large Ownership } \\
\text { (D1) }\end{array}$ & 165 & 0.6969 & 1 & 0 \\
\hline $\begin{array}{l}\text { Family Ownership } \\
\text { (D2) }\end{array}$ & 165 & 0.4545 & 1 & 0 \\
\hline $\begin{array}{l}\text { Institutional } \\
\text { Ownership (D3) }\end{array}$ & & 0.4242 & 1 & 0 \\
\hline AGE & 165 & 48.8121 & 198 & 6 \\
\hline GROWTH & 165 & 0.1936 & 3.4811 & -0.3987 \\
\hline LEV & 165 & 1.3650 & 70.831 & -31.036 \\
\hline SIZE & 165 & 28.0696 & 32.0846 & 25.1769 \\
\hline GDPG & 165 & 5.952 & 6.49 & 5.06 \\
\hline INF & 165 & 6.358 & 8.38 & 3.79 \\
\hline
\end{tabular}

Table 2 presents the descriptive statistics of each variables and also dummy variables. From this table, it shows that mean value of ROA is $11.69 \%$. In average this number is relatively high compare than central bank rate. The mean value of Tobin's Q is 14.0497 times. Large shareholders dominantly own the manufacturing company in Indonesia as the mean of large shareholder dummy is 0.6969. Moreover Indonesian companies are still controlled by owned by family (0.4545). Meanwhile, when we categorize the institution ownership and individual, there are 42 percent of the companies are owned by institutions

\section{IV.II. Regression Results and Analysis}

Table 3 reveals the result of the regression panel data; the dependent variables consist of ROA and TOBQ. Our finding shows that existence of large shareholders (more than 50 percent) do not affect the performance of company significantly both in term of accounting measurement ROA and market measurement TOBQ. This result different with the finding of Abbas et al (2013) who indicates a significant positive impact of concentrated ownership on firm performance. They argue that larger shareholders monitor the managements efficiently so that management can make higher performance. Different finding obtain by Isik \& Soykan (2013), these authors prove that large shareholders and firm value becomes negative when the concentration of ownership by large shareholders excess controlling level.

\begin{tabular}{|c|c|c|c|c|}
\hline \multirow{2}{*}{$\begin{array}{l}\text { Variables } \\
\mathrm{C}\end{array}$} & \multicolumn{2}{|c|}{ Dependent Variable ROA } & \multicolumn{2}{|c|}{ Dependend Variable TOBQ } \\
\hline & $\begin{array}{l}-0.3081 \\
(2.2656)\end{array}$ & $\begin{array}{l}-0.3633 \\
(0.191)\end{array}$ & $\begin{array}{l}-117.12 \\
(0.3066))\end{array}$ & $\begin{array}{c}-153.8063 \\
(0.1885)\end{array}$ \\
\hline $\begin{array}{l}\text { Dummy Large } \\
\text { Shareholder (D1) }\end{array}$ & $\begin{array}{c}0.2538 \\
(0.4903)\end{array}$ & & $\begin{array}{l}-12.4435 \\
(04219)\end{array}$ & \\
\hline $\begin{array}{l}\text { Dummy Family } \\
\text { Ownership (D2) }\end{array}$ & & 0.0226 & & $\begin{array}{l}-42.2241^{* *} \\
(0.041)\end{array}$ \\
\hline $\begin{array}{l}\text { Ownership (D2) } \\
\text { Dummy Institution }\end{array}$ & & $\begin{array}{l}(0.6607) \\
0.0868^{*}\end{array}$ & & $\begin{array}{l}(0.0411) \\
-33.3630^{*}\end{array}$ \\
\hline Ownership (D3) & & $(0.0947)$ & & $(0.086)$ \\
\hline Size of Assets & $\begin{array}{c}0.0037 \\
(0.6350)\end{array}$ & $\begin{array}{c}0.0042 \\
(0.6092)\end{array}$ & $\begin{array}{l}1.1882 \\
(06911)\end{array}$ & $\begin{array}{c}3.0953 \\
(0.2876)\end{array}$ \\
\hline AGE & $\begin{array}{c}0.0008 \\
(0.1723)\end{array}$ & $\begin{array}{c}0.0006 \\
(0.2440)\end{array}$ & $\begin{array}{c}0.5556 \\
(0.1704)\end{array}$ & $\begin{array}{c}0.5248 \\
(0.1984)\end{array}$ \\
\hline GROWTH & $\begin{array}{c}0.0047 \\
(0.4144)\end{array}$ & $\begin{array}{c}0.0043 \\
(04484)\end{array}$ & $\begin{array}{c}2.2096 \\
(0.4652)\end{array}$ & $\begin{array}{c}2.7962 \\
(0.3332)\end{array}$ \\
\hline LEV & $\begin{array}{l}-0.0002 \\
(0.7986)\end{array}$ & $\begin{array}{l}-0.0003 \\
(0.7685)\end{array}$ & $\begin{array}{c}0.3152 \\
(0.7070)\end{array}$ & $\begin{array}{c}0.3429 \\
(0.6435)\end{array}$ \\
\hline GDPG & $\begin{array}{l}0.0399 \text { *** } \\
(0.0124)\end{array}$ & $\begin{array}{c}0.0400^{* * *} \\
(0.012)\end{array}$ & $\begin{array}{c}10.4719^{* *} \\
(0.0301)\end{array}$ & $\begin{array}{l}10.3087 \\
(03073)\end{array}$ \\
\hline $\mathrm{INF}$ & $\begin{array}{c}0.0044 \\
(0.2530)\end{array}$ & $\begin{array}{c}0.0044 \\
(0.2501)\end{array}$ & $\begin{array}{c}2.8223 \\
(0.2558)\end{array}$ & $\begin{array}{c}2.9344 \\
(0.2344)\end{array}$ \\
\hline R Square & 0.1044 & 0.16 .22 & 0.0988 & 0.1192 \\
\hline
\end{tabular}

Family ownership has positive relationship with ROA, however this association is not significant. This finding is consistent with Pindado, Requejo, and Torre (2008), it shows that family have positive impacts on firm performance because the advantage related to family owners, such as the concern of their reputation. Institutional firms have greater values of ROA compare with family firms because institutional firms in general have higher profits before tax than family firms (Khan \& Khan, 2011). This dummy variable (family ownership) is negatively impact market value (TOBQ). This negative relationship occur, because market might perceive a higher risk of disgorging cash flow by family that control company. Shyu (2011) found that the negative relationship between family ownership and Tobin's Q possibly caused by the high volatility of capital market in Taiwan. 
The next ownership dummy variable is institution. This variable has positive association with accounting measure ROA. It seems that the majority share holder (institution) oversee the company management and performance tightly, so that the performance of firms become better when the proportion of institution ownership increase. However, the same case with the majority of ownership is family, market also responds negatively with this condition even thought this type of owner succeed in controlling the management to improve firm performance by accounting measure. This result may arise because the market is frightened by the behavior of majority owners to expell cash from the company at the expense of the minority shareholders. Our result is in accordance with the finding of Charfeddine and Elmarzougui (2010).

The control variables such as SIZE, AGE, and GROWTH show positive relationship with firm performance, however this relationship is not significant. It is consistent in Abdullah, Shah, \& Khan (2012) research, which indicates a positive effect between firm size and ROA. Larger size supports a firm to have more economies scale, lower the information asymmetry and lower possibility to bankrupt. Meanwhile other control variables LEV (leverage), has negative relationship with firm performance. Naqvi and Mirza (2013) also show that leverage has negative impacts with firm performance, these authors argue that a lot of money has to pay the interest expense for the excessive debts.

GDP shows significant and positive relationship while INF has insignificant positive relationship with firm performance. Economic growth positively affect the business, this finding is in line with the results of Levine, Loayza, and Beck (2000) highlight the positive relationship between the development of financial institutions and economic growth.

\section{CONCLUSIONS}

This research investigates the effect of majority shareholder on firm performance in consumer goods companies listed in Indonesia Stock Exchange period 20102014. The samples total are 33 companies listed in Indonesia Stock Exchange. Performance of the firms is measure by accounting ROA measurement and market performance measurement namely Tobin Q (TOBQ). We distinguish ownership variables into three categories; the first one is the majority shareholder with the proportion ownership bigger than fifty percent without concern on who the owners are. The second dummy ownership variable is the family ownership and the last one is the institution owners.

Our regression finds that there is no relationshipbetweenmajority shareholders and firm performance. Family ownership has negative impact on market value (TOBQ), it results arise probably because market is afraid on the bigger control of family in the firm that could expel the cash flow of company only for the wealth of family circle in the company. The same respond from market also occur when the majority of shareholder is institutions, frightening of disgorging cash flows from company negatively affect the market value of firms.

Our finding provides the signal for company which majority of shareholder is family and institutions, they have to be alert that market perceive a higher risk of disgorging cash flow by family and institution who control the company, so that it impact negative on the firm 
value. Additionally for the new investors who expect to have capital gain on the investment must take fully concern on this condition, because their value of investment could decrease and get loss if they invest in this type of companies.

\section{REFERENCES}

Abbas, A., Naqvi, H., \& Mirza, H. (2013). Impact of Large Ownership on Firm Performance: A Case of non Financial Listed Companies of Pakistan. World Applied Sciences Journal

Abukosim, Mukhtaruddin, Ferina, I., \& Nurchaya, C. (2014). Ownership Structure and Firm Value: Empirical Study on Indonesia Manufacturing Listed Companies. Journal of Arts, Science \& Commerce.

Abdullah, F., Shah, A., \& Khan, S. (2012). Firm Performance and the Nature of Agency Problems in Insiders-Controlled Firms: Evidence from Pakistan. The Pakistan Development Review

Ahmed, K., Sehrish, S., Saleem, F., \& Yasir, M. (2012). Impact of Concentrated Ownership on Firm Performance (Evidence from Karachi Stock Exchange). Interdisciplinary Journal of Contemporary Research in Business.

Alipour, M. (2013). An Investigation of the Association Between Ownership Structure and Corporate Performance: Empirical Evidence from Tehran Stock Exchange (TSE. Management Research Review

Al-Saidi, M., \& Al-Shammari, B. (2014). The Relationship between a Firm's Value and Ownership Structure in Kuwait: Simultaneous Analyses Approach. International Business Research
André, P., \& Ben-Amar, W. (2008). Family Ownership, Agency Problems, Corporate Governance and Acquiring Firm Shareholder Wealth: Evidence from Acquisitions of New Economy Firms. Social Sciences and Humanities Research Council of Canada.

Arosa, B., Iturralde, T., \& Maseda, A. (2009). Ownership Structure and Firm Performance in Non-Listed Firms: Evidence from Spain. World Family Business Research Conference of IFERA

Barbera, F., \& Hasso, T. (2013). Do We Need to Use an Accountant? The Sales Growth and Survival Benefits to Family SMEs. Family Business.

Baker, H., \& Martin, G. (2011). Capital Structure and Corporate Financing Decisions: Theory, Evidence, and Practice. Washington: John Wiley \& Sons.

Charfeddine, L., \& Elmarzougui, A. (2010). Institutional Ownership and Firm Performance: Evidence from France. The IUP Journal of Behavioral Finance.

Charitou, A., \& Louca, C. (2014). Corporate Governance, Agency Problems, and Firm Performance: Empirical Evidence from an Emerging European Market. Cyprus University of Technology and Durham

Chinaemerem, O., \& Anthony, O. (2012). Impact of Capital Structure on the Financial Performance of Nigerian Firms. Arabian Journal of Business and Management Review.

Chung, K., \& Zhang, H. (2009). Corporate Governance and Institutional Ownership. Journal of Financial and Quantitative Analysis.

Claessens, S., Djankov, S., \& Lang, L. (2000). The Separation of Ownership and Control in East Asian Corporations. 
Journal of Financial Economics

D'Amato, E. (2010). The Top 15 Financial Ratios. Australian Shareholders' Association.

David, P., O’brien, J., Yoshikawa, T., \& Delios, A. (2010). Do Shareholders or Stakeholders Appropriate the Rents from Corporate Diversification? The Influence of Ownership Structure. Academy of Management Journal.

Demsetz, H., \& Villalonga, B. (2001). Ownership Structure and Corporate Performance. Journal of Corporate Finance.

Dwivedi, D. (2010). Macroeconomics Theory and Policies. New Delhi: Tata McGraw-Hill.

Foroughi , M., \& Fooladi , M. (2012). Concentration of Ownership in Iranian Listed Firms. International Journal of Social Science and Humanity.

Graham, J., \& Smart, S. (2011). Introduction to Corporate Finance: What Companies Do, Abridged Edition. USA: Cengage Learning.

Haruman, T. (2008). Pengaruh Struktur Kepemilikan Terhadap Keputusan Keuangan dan Nilai Perusahaan: Survey pada Perusahaan Manufaktur di PT. Bursa Efek Indonesia. Simposium Nasional Akuntansi IX.

Hasan, M., Ahsan, A., Rahaman, M., \& Alam, M. (2014). Influence of Capital Structure on Firm Performance: Evidence from Bangladesh. International Journal of Business and Management.

Hitt, M., Ireland, R., \& Hoskisson, R. (2012). Strategic Management: Concepts: Competitiveness and Globalization. United States: Cengage Learning

Isik, O., \& Soykan, M. (2013). Large
Shareholders and Firm Performance: Evidence From Turkey. European Scientific Journal.

Jaisawal, D., Srivastava, D., \& Sushma. (2013). Role of Capital Structure in Defining Financial Performance: A Study with Respect to Cement Industry in India. International Journal of Applied Financial Management Perspectives

Jebri, A. (2013). The Effect of Large Controlling Shareholder's Presence and Board of Directors on Firm Value. International Journal of Accounting and Financial Reporting.

Karaca, S., \& Ekşi, İ. (2012). The Relationship between Ownership Structure and Firm Performance: An Empirical Analysis over İstanbul Stock Exchange (ISE) Listed Companies. International Business Research

Khan, M., \& Khan, F. (2011). Does Ownership Matter? A Study of Family and Non-Family Firms in Pakistan. Problems of Management in the 21st Century.

King, T.-H., Tian, W., \& Zhang, C. (2009). Corporate Governance, Active Shareholder and Ownership Structure. Conference on Risk Management and Corporate Governance

Laiho, T. (2011). Agency Theory and Ownership Structure - Estimating the effect of ownership structure on firm performance. Aalto University School of Economics.

Lessambo, F. (2013). The International Corporate Governance System: Audit Roles and Board Oversight. New York: Palgrave Macmillan

Levine, R., Loayza, N., \& Beck, T. (2000). Financial intermediation and growth: Causality and causes. Journal of Monetary Economics, 46(1), 31-77 
Margaritis , D., \& Psillaki, M. (2008). Capital Structure, Equity Ownership and Firm Performance. Journal of Banking \& Finance.

Mireku, K., Mensah, S., \& Ogoe, E. (2014). The Relationship between Capital Structure Measures and Financial Performance: Evidence from Ghana. International Journal of Business and Management

Network for Business Sustainability. (2015). Retrieved from Tobin's Q or the Q Ratio: http://nbs.net/tobins-q-or-the-qratio/

Nirajini, A., \& Priya, K. (2013). Impact of CapitalStructure on FinancialPerformance of the Listed Trading Companies in Sri Lanka. International Journal of Scientific and Research Publications.

Ongore, V. (2011). The Relationship Between Ownership Structure and Firm Performance: An Empirical Analysis of Listed Companies in Kenya. African Journal of Business Management.

Pandey, I. (2009). Financial Management. New Delhi: Vikas Publishing House Pvt Ltd.

Pindado, J., Requejo, I., \& Torre, C. (2008). Does Family Ownership Impact Positively on Firm Value? Empirical Evidence from Western Europe. Dpt. Administración y Economía de la Empresa

Petty, J., Titman, S., Keown, A., Martin,
P., Martin, J., Burrow, M., \& Nguyen, H. (2011). Financial Management: Principles and Applications. Australia: Pearson Higher Education AU.

Sacristán-Navarro, M., Gómez-Ansón, S., \& Cabeza-García, L. (2011). Family Ownership and Control, the Presence of Other Large Shareholders, and Firm Performance: Further Evidence. Family Business Review.

SDSS. (2014). Retrieved from Quarterly Domestic Product by Industrial Origin at Current Prices: http://www.bi.go.id/sdds/ series/NA/index_NA.asp

Shyu, J. (2011). Family Ownership and Firm Performance: Evidence from Taiwanese Firms. International Journal of Managerial Finance.

Siddaiah, T.(2010). International Financial Management. Pearson Education India: India.

Shleifer, A., \& Vishny, R. (1986). Large Shareholders and Corporate Control. Journal of Political Economy.

Twairesh, A. (2014). The Impact of Capital Structure on Firm's Performance: Evidence from Saudi Arabia. Journal of Applied Finance \& Banking.

Wright, M., Siegel, D., Keasey, K., \& Filatotchev, I. (2013). The Oxford Handbook of Corporate Governance. United Kingdom: Oxford University Press. 